\title{
Wages, Prices and Unemployment in Poland
}

\section{Introduction}

The paper aims to analyze long-run relationships between labor market trends, wages, prices, interest rates and the exchange rate in Poland. As a nonparticipating member of the European Monetary Union, Poland plans to adopt the common European currency in the future. Adopting the euro, however, is connected with the loss of two adjustment mechanisms, an autonomous monetary policy and the nominal exchange rate. This means that other adjustment mechanisms, including fiscal policy, labor and the product market, will have to react effectively in case of asymmetric shocks. The optimal currency area theory underlines the role of the labor market (both through wages and labor mobility) and the product market (through prices) in particular.

Poland is in the process of catching up with more advanced European economies. The country's GDP and productivity growth rates are therefore higher than those of euro-area member countries. Higher productivity growth leads to higher price and wage growth rates. Over the past several years the Polish economy has had some successful experience in curbing inflation and promoting economic growth and employment. The question is if there are any useful lessons to be learned from studying the adjustment mechanisms in Poland during the convergence period. In particular, wage and price rigidities are widely recognized as a crucial issue for monetary policy. Such knowledge can be useful to better foresee (and hopefully avoid) future problems, in particular those concerned with the necessity of meeting the Maastricht criteria before adopting the euro.

As far as the methodology is concerned, in the paper we use cointegrated VAR analysis, which makes it possible to identify long-run tendencies and common stochastic trends as well as estimate the adjustment dynamics of the system (the pulling and pushing forces). In formulating the model we follow the existing literature in the area [Juselius, Ordonez, 2009], [Marquez, 2008], [Juselius, 2006], [Todano, 2006], [Buscher et al., 2005], [Brüggemann, 2003], [Welfe, Kelm, Majsterek, 2002], [Balmaseda, Dolado, Lopez-Salido, 2000], [Marcellino, Mizon, 1999], [Henry, Karanassu, Snower, 1999], [Welfe, Osiewalski, 1998], [Dolado, Jimeno, 1997], [King et al., 1991].

The authors work at the National Bank of Poland and the University of Łódź, Poland, e-mail: sylwiaroszkowska@wp.pl; arogut@uni.lodz.pl. The paper was submitted in May 2010. The usual disclaimer applies. 
The structure of the paper is as follows. First, we briefly describe the theoretical background of the model. Second, the data and labor market situation in Poland in the analyzed (1995-2009) period are described. Next, we describe the model. Finally, the econometric results are shown and we conclude.

\section{Theoretical background}

In our paper, we follow the existing literature and we analyze a simple model of an economy with imperfect competition on both the labor and product markets. We assume that consumers maximize their utility from consumption and leisure subject to the budget constraint and that producers maximize their profits. Wages are determined by the bargaining process between employers and unions [Layard et al., 1991]. The bargaining solution depends on the relative power of employers and unions (see also [Juselius, 2006]).

\section{The behavior of employers}

Employers bargain over real product wages, which are determined by labor productivity and product prices. During the negotiation process, they tend to maximize the markup over unit labor costs (see [Juselius, 2006]):

$$
-\left(w_{t}-p_{y t}-y_{t}\right)
$$

accounting for the anticipated effect of the real product wage increase on its competitiveness.

The markup is assumed to be a function of the real exchange rate, real interest rate and inflation rate:

$$
-\left(w_{t}-p_{y t}-y_{t}\right)=f\left(e r_{t}^{e}, R_{t}^{e}, \pi_{t}\right)+v_{1 t}
$$

where:

$e r_{t}^{e}=\left(e n_{t}-p^{f}-p_{y t}\right)_{t}^{e}-$ is the real exchange rate at time $t$, $R_{t}^{e}-$ is the real interest rate at time $t$, $\pi_{t}-$ is the inflation rate at time $t$.

The first derivatives are positive, which implies a lower markup as a result of a real appreciation, a lower markup as a result of a rise in the real interest rate and a negative effect on the markup from inflation.

\section{The behavior of unions}

Unions tend to increase the impact of real consumer wages on the level of productivity. The important factor is the state of the labor market: the better the situation on the labor market, the higher the unions' wage pressure. 
Moreover, the higher inflation, the higher the wage pressure. We can express this as follows (see [Juselius, 2006]):

$$
\left(w_{t}-p_{e t}-y_{t}\right)=g\left(u_{t}, \Delta p_{t}\right)+v_{2 t}
$$

The effect of inflation on real wages depends on the nature of wage agreements, in particular on the existence of indexation clauses - the wage indexation mechanism is considered to be one of the main determinants of inflation and its persistence.

\section{The observed wage level}

The wage level observed on the market is a function of the bargaining power of unions and employers. The outcome of the negotiations is therefore the weighted average of the real consumption wage and real product wage corrected for productivity [Linzert, 2001]:

$$
\begin{aligned}
\omega\left(w_{t}-p_{c, t}-y_{t}\right) & +(1-\omega)\left(w_{t}-p_{y t}-y_{t}\right)=\omega g\left(u_{t}, \Delta p_{t}\right)+ \\
& +(1-\omega) f\left(e_{t}^{e}, R_{t}^{e}\right)+v_{3 t}
\end{aligned}
$$

where:

$\omega-$ is the indicator of the union's power. The higher the value of $\omega$, the stronger is the bargaining power of employees.

After some transformations the wage equation is follows:

$$
\left.w_{t}-p_{c, t}=a_{0}+a_{1}\left(p_{c, t}-p_{y, t}\right)+y_{t}+a_{2} u_{t}+a_{3} \Delta p_{t}+a_{4} e r_{t}+a_{5} R_{t}\right)+v_{3 t}
$$

where $a_{1}=-(1-\omega)$.

The wage level observed on the market is then the higher:

- the stronger is the bargaining power of unions,

- the lower is the unemployment rate $\left(a_{2}<0\right)$,

- the higher is the inflation rate $\left(a_{3}>0\right)$,

- the higher is the value of the exchange rate (depreciation of domestic currency, $\left(a_{4}>0\right)$,

- the higher is the real interest rate $\left(a_{5}>0\right)$.

\section{The price wedge}

Turning to prices, after subtracting the producer's wage equation from the consumer's wage equation we have (see [Juselius, 2006]):

$$
p_{e t}-p_{y, t}=a_{1}+a_{2} \Delta p_{c, t}+a_{3} u_{t}+a_{4} R_{t}+a_{5} e r_{t}+v_{3, t}
$$


where the price wedge is a positive function of inflation, the exchange rate and the interest rate and a negative function of the unemployment rate. Moreover, following the literature, among factors important for the price wedge we can list:

- the degree of wage negotiations (the more centralized is the level of wage negotiations, the growth of producer's wages is more similar to the growth of consumers' wages, which influence the price wedge),

- product market competition (the more competitive the market, the lower the pressure on product prices and the higher the price wedge),

- import prices (greater impact of the competitive environment on consumer prices and a higher price wedge).

The stationarity of the price-wedge equation may imply several possible specifications, as the Phillips curve relation [Phillips, 1958], [Phelps, 1967]:

$$
\Delta p_{c, t}=a_{6}+a_{7} u_{t}+v_{4, t}
$$

where the inflation rate is the negative function of the observed unemployment rate.

\section{Labor productivity and unemployment}

To maintain the competitiveness of the economy in an increasingly globalized and competitive environment, the growth of real wages has to be compensated for with the growth of labor productivity.

Two ways of improving labor productivity growth are possible. The growth of productivity can be achieved through technological progress or through a decrease in employment. Considering that an improvement in technology is usually very costly, a decrease in employment can more often be observed, at least in the short and medium term. If $y_{t}-b_{1} t \sim I(1)$ and cointegrates with unemployment, it will be interpreted as evidence that the growth in labor productivity has been achieved by reducing employment (see [Juselius, 2006]).

There are, however, important implications for the behavior of prices. If labor productivity growth has been achieved by reducing employment, output prices will not increase as much as wages, so the price wedge will increase. This relation can be illustrated as follows (see [Juselius, Ordonez, 2009], [Fabiani, Locarno, Oneto, Sestito, 2001]):

$$
\left(y_{t}-b_{1} t\right)=a_{6}+a_{7} u_{t}+a_{8}\left(p_{c, t}-p_{y, t}\right)+v_{4, t}
$$

where productivity grows with the unemployment rate $\left(a_{7}>0\right)$ and with the price wedge $\left(a_{8}>0\right)$.

Analogically, we can illustrate this hypothesis by:

$$
u_{t}=a_{11}+a_{12}\left(y_{t}-b_{1} t\right)+a_{13}\left(p_{c, t}-p_{y, t}\right)+v_{4, t}
$$


where the unemployment rate grows with productivity $\left(a_{12}>0^{1}\right)$ and the price wedge $\left(a_{13}>0\right)$ and $v_{4, t} \sim I(0)$.

\section{Long-run price homogeneity and inflation adjustments}

When nominal variables are $I(2)$, inflation is $I(1)$. Under the long-run price homogeneity, relative prices are $I(1)$ and we would expect cointegration between them and the inflation rate. The inflation rate could be cointegrated with the domestic price wedge, the foreign price wedge and/or real wages in excess of productivity (see [Juselius, 2006], [King, Plosser, Watson, 1991]):

$$
\Delta p_{c, t}=a_{14}+a_{15}\left(p_{c}-p_{y}\right)_{t-1}+a_{16}(-e r)_{t-1}+a_{17}\left(w-p_{c}-y\right)_{t-1}+v_{7, t}
$$

where:

$a_{15}<0, a_{16}<0, a_{17}>0$ and $v_{7, t} \sim I(0)$.

The magnitude and significance of the parameters indicate which factors are the most important for the long-run inflation path. An equilibrium correction will take place when $\left(p_{c}-p_{y}\right)$ increases more than er or the other way round. The BS correction on relative prices assumes $a_{15}=-a_{16}$.

From the theoretical model described above and from the empirical literature we can formulate some research hypotheses, which we will try to verify in the empirical part of the paper:

Hypothesis 1: In Poland's case (catching-up economy), the inflation rate is likely to be influenced by the BS effect. If this is the case, the price wedge will increase with a decrease (appreciation) of the real exchange rate.

Hypothesis 2: Globalization and Poland's integration with the European economy will lead to an increased competition effect.

\section{Data and labor market trends in Poland}

Following the theoretical aspects discussed in the previous part, we will now focus on seven variables: real wages $(w)$, labor productivity $(y)$, the unemployment rate $(u)$, inflation $(C P I)$, the price wedge $(C P I / P P I)$, the long-term interest rate $(R)$, and the real exchange rate (PLN/EUR).

All the data have been taken from Poland's Central Statistical Office (CSO). We use quarterly data. The analyzed sample is $1995,1-2009,2$. The length of the sample is due to the availability of statistical data.

Looking at the situation on the Polish labor market in the analyzed period (see Figure 1.1. in Annex 1), we can see that the market followed the business

1 We have to underline that the effects of productivity on unemployment are difficult to determine a priori. On the one hand, productivity can be expected to reduce labor demand, but on the other the implied lower product prices and higher wages stimulate aggregate demand and thus the demand for labor. 
cycle. After an initial period of economic expansion and falling unemployment (in 1995-1998 the average annual GDP growth rate was above 5\%), the unemployment rate increased significantly in 1999-2003 (in 2003, the unemployment rate in Poland reached 20\%). In 2004-2008, due to a process of economic recovery as well as significant migration outflows from Poland after the country's European Union entry, the unemployment rate decreased to its lowest level since 1990 (below 8\%).

Due to the process of transformation and the restructuring of the Polish economy, we can notice a significant growth in labor productivity. However, the growth rate decreased from about 4\% in 1995-1998 and even 7-8\% in 1999-2000 (mostly due to a significant decrease in employment) to a modest 2-3\% in the second part of the sample (see Figure 1.2 in Annex 1).

Real wages followed labor productivity, however for most of the analyzed period real wages grew at a slower rate than labor productivity. That changed after 2005, when a shortage of labor force (due to an economic recovery and a migration process) put pressure on wage growth (see Figure 1.3 in Annex 1).

Looking at the inflation rate, we can see huge changes in the analyzed period. The process of transformation was connected with a stabilization in the inflation rate, which fell from about $20 \%$ at the beginning of the sample to under 5\% after 2001 (see Figure 1.4 in Annex 1).

Analyzing the price wedge (the difference between the CPI and PPI) we can see quite a different picture in the first and second part of the sample. In 1995-2000, the price wedge increased continually. After 2001 it stabilized (see Figure 1.5 in Annex 1).

The real interest rate behaved in a way similar to the inflation rate. During the analyzed period it stabilized from a relatively high level of over $20 \%$ to around 5-6\% in the last few years of the sample (see Figure 1.6 in Annex 1).

Looking at the real exchange rate we have to underline that until 2000 we had the crawling peg regime, which in April 2000 was transformed into a flexible exchange rate regime. In 2000-2004, the Polish zloty depreciated, a process that was followed by a strong appreciation after the country's EU accession in 2004. A global economic slowdown was one of the reasons behind a strong depreciation of the zloty against the euro in the second part of 2008 (see Figure 7 in Annex 1).

\section{The model}

Following the theoretical background, we construct a simple VAR model linking the above-described variables.

We follow the full specification process to carefully check for signs of misspecification problems (the residuals are in Annex 2). The values of the residual analyses indicate that we do not have any serious deviations from the basic assumptions of residual independence, homoscedasticity and normality.

As far as the deterministic components are concerned, we check the model specification with the unrestricted trend option. The results indicate that a trend 
can be excluded from the cointegration relation independently of the number of cointegration relations. Since we have a trend in the data (in labor productivity, real wages) we decided to estimate the model with an unrestricted constant.

A lag length determination test indicates that there are two lags.

As far as the stability of parameters is concerned, the test for beta constancy indicates that there are no serious problems with the constancy of the parameters. However, we are aware that complete parameter constancy is hard to guarantee at a time of significant changes in the economy, so the values of the estimated parameters should be interpreted as average effects over the analyzed period.

In line with the above description, we end up with the following VAR model:

$$
\begin{aligned}
& \left(\begin{array}{l}
u_{t} \\
w_{t} \\
y_{t} \\
\Delta p_{t} \\
C P I_{t} / P P I_{t} \\
R_{t} \\
e r_{t}
\end{array}\right)=\pi_{1}\left(\begin{array}{l}
u_{t-1} \\
w_{t-1} \\
y_{t-1} \\
\Delta p_{t-1} \\
C P I_{t-1} / P P I_{t-1} \\
R_{t-1} \\
e r_{t-1}
\end{array}\right)+\pi_{2}\left(\begin{array}{l}
u_{t-2} \\
w_{t-2} \\
y_{t-2} \\
\Delta p_{t-2} \\
C P I_{t-2} / P P I_{t-2} \\
R_{t-2} \\
e r_{t-2}
\end{array}\right)+\mu_{t}+\phi D U M+\zeta_{t} \\
& t=1,2, \ldots, T,
\end{aligned}
$$

where:

$\mu$ is the constant terms vector,

$\pi_{s}$ is the parameter matrix ( $s=1,2-$ the number of lags),

$D U M$ - vector of dummy variables,

$\zeta_{t}$ is the vector of error terms.

A trace test with a Bartlett correction for the small sample indicates that the cointegration rank is 5 (see Table 3.1 in Annex 3, however the substantial differences between the p-value with and without the Bartlett correction indicate that probably there is a problem with I(2) in the model (in the case of the unemployment rate). Moreover, the roots of the companion matrix indicate that $r=5$ seems to be the best solution. The cointegrating vectors are presented in Figure 3.1 in Annex 3.

The weak exogeneity test shows that only the exchange rate can be considered as a weak exogenous variable in the model (with a p-value of 0,396 , see Table 3.2 in Annex 3).

The result of the unit root test indicates that real wages, inflation and the price wedge are purely adjusting variables. Labor productivity is on the borderline (with the p-value at 0,055; see Table 3.3 in Annex 3).

The values of a joint test of unit vector in alpha show that only the inflation rate, wages and the price wedge are purely adjusting variables in the model (see Table 3.4 in Annex 3). 
The test of long-run exclusion indicates that we cannot exclude any of the variables in the model. The test of variable stationarity shows that all the variables are not stationary.

As we mentioned above, we have five cointegrated relations in the model. After testing for all possible combinations, we managed to identify the beta structure. The structure of cointegration relations is accepted based on a $p$-value of 0.204 (see Table 3.5 in Annex 3).

\section{Empirical results}

The first cointegration relation relates the inflation rate to the real exchange rate, which shows that the Polish inflation rate has been equilibrium-correcting to the euro-area price level represented by the euro price:

$$
D \hat{C} P I=0.069 E
$$

Looking at the magnitude of the parameter we can see that the coefficient is higher (compared with other results from the literature), testifying to a relatively fast price adjustment in Poland.

The second cointegration relation can be interpreted as an affordable and acceptable wage relation describing the relative power of the employers' and the employees' unions as a function of the unemployment rate and productivity growth:

$$
\hat{W}=0.8 Y-1.2 U
$$

All the signs of the parameters are consistent with economic theory. Real wages depend positively on labor productivity with an elasticity of 0.8 . Moreover, labor market tightness matters in the process of forming real wages. The higher the observed unemployment rate, the lower the bargaining position of employees and the lower the pressure on wages.

The third cointegration relation shows that the unemployment rate has been co-moving with labor productivity and the price wedge:

$$
\hat{U}=-0.72 Y+2.17 \text { Price_Wedge }
$$

The negative sign in the case of labor productivity's impact on unemployment can be interpreted as a structural process. The productivity growth implies changes in the labor demand structure, with an increased demand for whitecollar workers and reduced demand for blue-collar workers. In convergence countries such as Poland, the net effect is positive, which implies a lower unemployment rate.

The fourth cointegration relation describes the co-movements between the price wedge and the exchange rate, which can be treated as a kind of BalassaSamuelson effect: 


$$
\text { Price Wedge }=-0.28 E
$$

The fifth cointegration relation relates labor productivity to the real exchange rate and the real interest rate:

$$
\hat{Y}=0.27 E-3.87(R-D C P \hat{I})
$$

As explained in the theoretical part of the paper, the appreciation of the real exchange rate in a competitive environment implies adjustment through labor productivity growth. Lower costs of capital due to lower real interest rates will have a positive impact on productivity.

Looking at the two common stochastic trends, we can interpret them as follows. The first common stochastic trend seems to be measured by the cumulated shocks to productivity. In the long run, this seems to have a negative (borderline significant) impact on producer prices, thus increasing the price wedge (increased competition effect), as well as a negative impact on the real interest rate (capital liberalization effect). The second common stochastic trend seems to be measured by cumulated shocks to the exchange rate, interest rate, productivity and unemployment.

\section{Conclusions}

The first, preliminary results of the model show that we can find stable long-run cointegration relations between the unemployment rate, wages and prices.

We can confirm our two main research hypotheses formulated on the basis of theoretical formulations. First of all, increasing product market competition effects during the analyzed period seem to be the main driving force behind the convergence of the Polish economy to more advanced European economies. Second, we can confirm that the Polish inflation rate has adjusted over the long run to the European purchasing power parity level and we can also confirm the Balassa-Samuelson effect for consumer prices.

The results are especially important in the context of Poland's expected entry to the euro area. The increase in competition seems to be the factor which stabilizes the pressure on prices even at a time of economic growth.

However, we have to underline that the results should be interpreted with some caution. One of the problems is the relatively short sample period, which is due to the transition period in Poland. Another problem is the presence of I(2)-ness symptoms in the data which can be seen in the model and which makes it impossible to analyze short-run dynamic adjustments between the variables. Moreover, the results indicate that some structural components can play a significant role in explaining the relations between the analyzed variables. This is our plan for future research. 


\section{References}

Balmaseda M., Dolado J., Lopez-Salido J.D., [2000], The Dynamic Effects of Shocks to Labour Markets: Evidence from OECD Countries, „Oxford Economic Papers”, Oxford University Press, Vol. 52(1), pp. 3-23.

Brüggemann I., [2003], Measuring Monetary Policy in Germany: A Structural Vector Error Correction Approach, „German Economic Review”, Blackwell Publishing, Vol. 4, pp. 307-339.

Buscher H., Dreger Ch., Ramos R., Surinach J., [2005], The Impact of Institutions on Employment Performance in European Labour Markets, IZA Discussion Papers.

Dolado J., Jimeno J., [1997], The causes of Spanish unemployment: A structural VAR approach, „European Economic Review” 41.

Fabiani S., Locarno A., Oneto G.P., Sestito P., [2001], The sources of unemployment fluctuations: An empirical application to the Italian case, "Labour Economics” 8.

Henry B., Karanassou M., Snower D., [1999], Adjustment Dynamics and the Natural Rate: An Account of UK Unemployment, IZA Discussion Papers, No. 75.

Jacobson T., Vredin A., Warne A., [1997], Common trends and hysteresis in Scandinavian unemployment, „European Economic Review”, No. 41, 1781-1816.

Juselius K., [2006], The Cointegrated VAR, Methodology and Applications, Oxford University Press.

Juselius K., Ordonez J., [2009], Balassa-Samuelson and Wage, Price and Unemployment Dynamics in the Spanish Transition to EMU Membership, http://www.economics-ejournal.org/economics/ journalarticles/2009-4

King R.G., Plosser C.I., Watson M.W., [1991], Stochastic trends and economic fluctuations, The „American Economic Review”, 81, 819-840.

Layard R., Nickell S., Jackman R., [1991], Unemployment, Oxford University Press.

Linzert T., [2001], Sources of German Unemployment: Evidence from a Structural VAR Model, ZEW Discussion Paper No. 01-40.

Marcellino M., Mizon G.E., [1999], Modeling shifts in the wage-price and unemployment-inflation relationships in Italy, Poland and the UK, „Economic Modelling”, No. 17.

Marquez C.B., [2008], Wage and price dynamics in Portugal, ECB Working Paper No. 945.

Phelps E.S., [1967], Phillips curves, expectations of inflation, and optimal unemployment over time, „Economica”, 34, 254-281.

Phillips A.W.H., [1958], The relation between unemployment and the rate of change of money wage rates in the United Kingdom, 1861-1957, „Economica”, 25, 283-299.

Todano K.R., [2006], A partial VAR analysis of wages and price formation in South Africa, South African Reserve Bank.

Welfe A., Kelm R., Majsterek M., [2002], Agregatowy model inflacji, „Przegląd Statystyczny”, Vol. 49, No. 3.

Welfe A., Osiewalski J., [1998], The Price Wage Mechanism: An Endogenous Switching Model, „European Economic Review”, Vol. 42, No. 2. 


\section{Annex 1}

\section{Statistical data (all the variables are in levels and first differences)}

Figure 1.1. Unemployment rate in Poland in 1995,1 - 2009,2 (\%)

$\mathrm{U}$

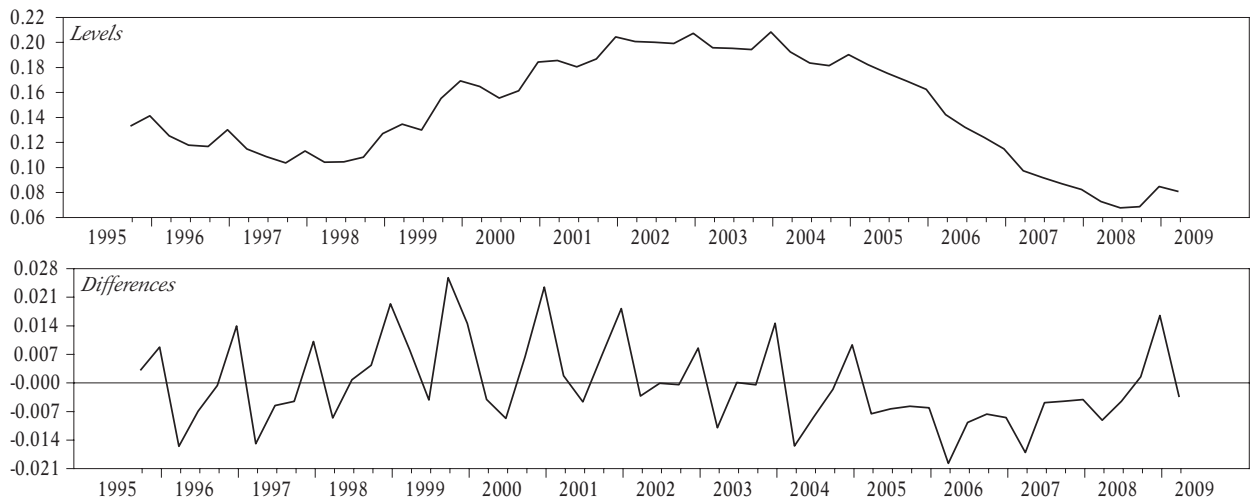

Source: CSO, www.stat.gov.pl, own estimates

Figure 1.2. Log of labor productivity (GDP per employed) in Poland in 1995,1 - 2009,2 (constant 2000 prices)

Y
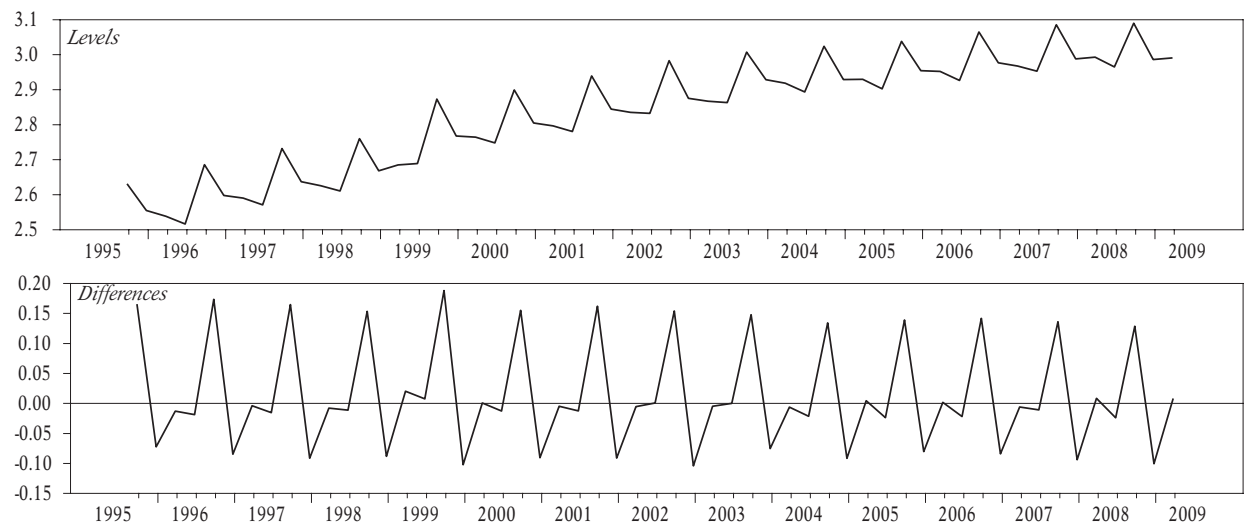

Source: CSO, www.stat.gov.pl, own estimates 
Figure 1.3. Log of real wages (nominal wages deflated with CPI) in Poland in 1995,1 - 2009,2

W
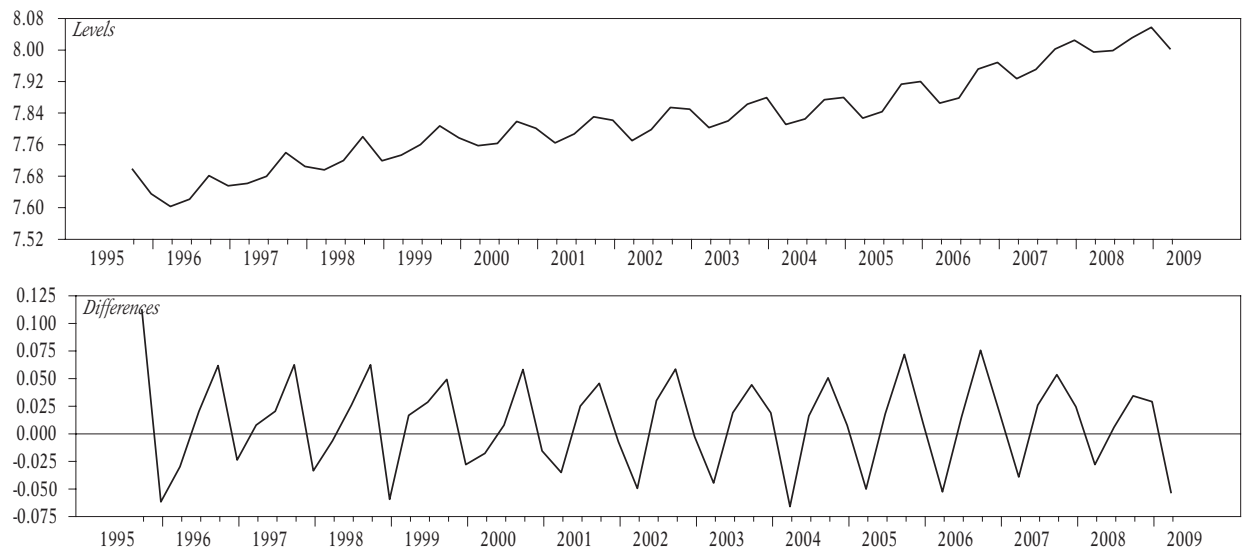

Source: CSO, www.stat.gov.pl, own estimates

Figure 1.4. Log of inflation rate (CPI) in Poland in 1995,1 - 2009,2 (\%)

DCPI
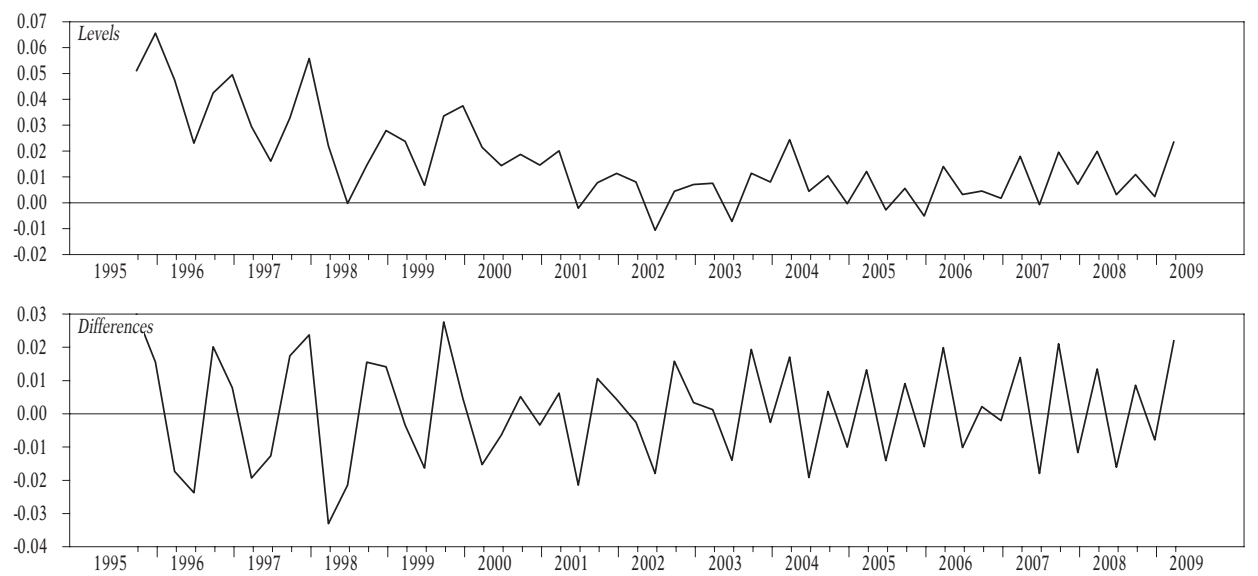

Source: CSO, www.stat.gov.pl, own estimates 
Figure 1.5. Price wedge (CPI-PPI) in Poland in 1995,1 - 2009,2

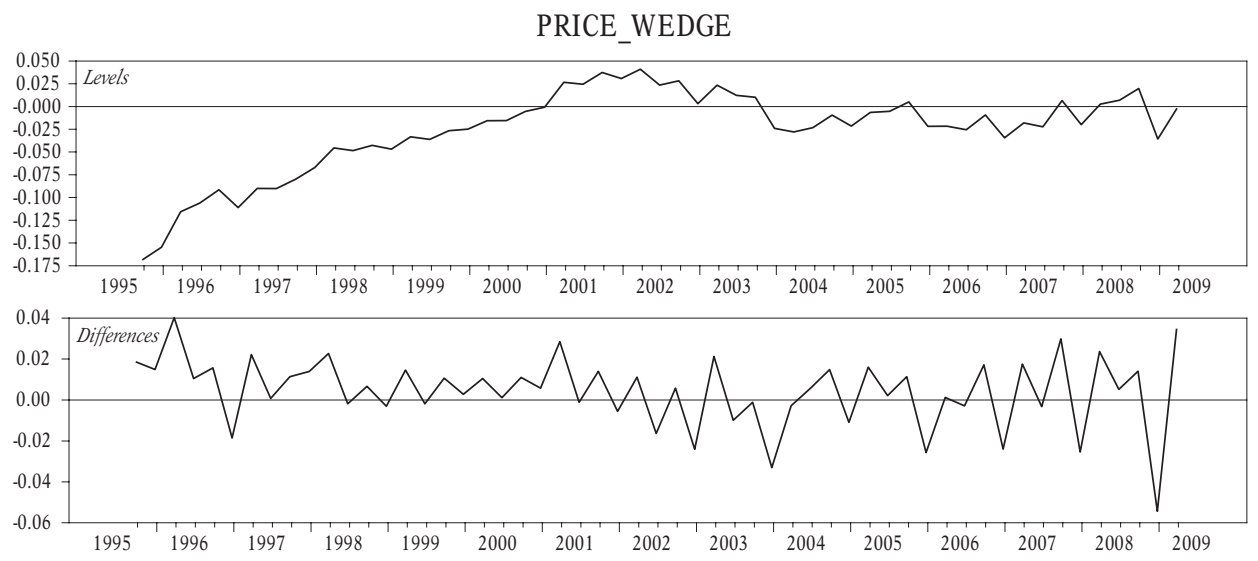

Source: CSO, www.stat.gov.pl, own estimates

Figure 1.6. Nominal interest rate in Poland in 1995,1 - 2009,2 (10-year bond rate)

$\mathrm{R}$
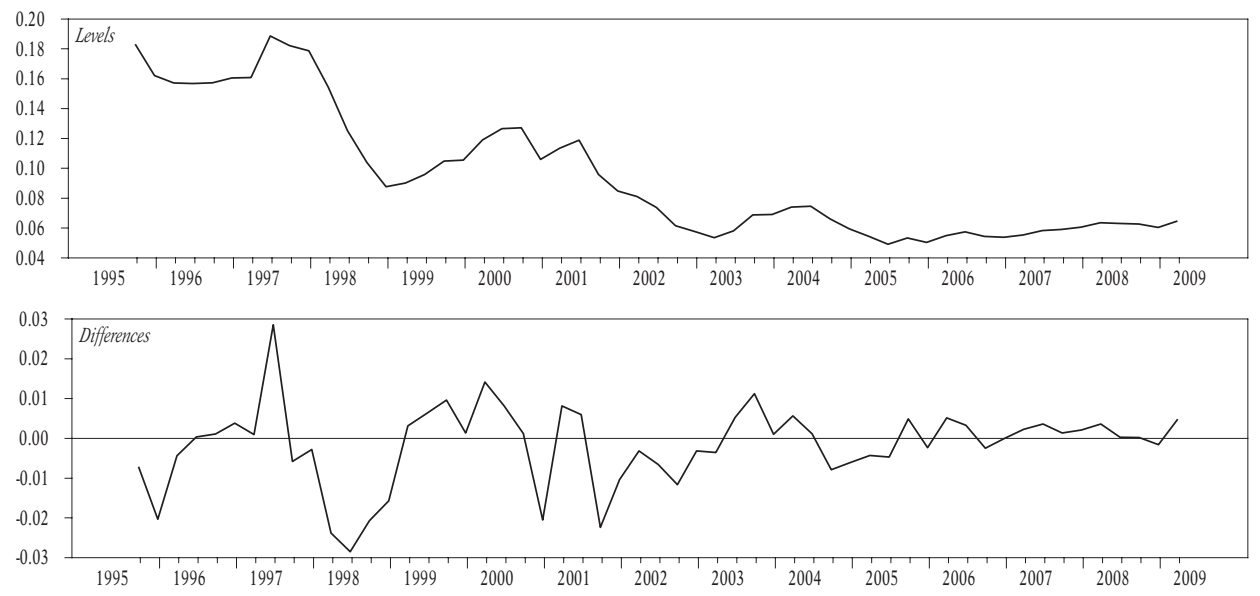

Source: CSO, www.stat.gov.pl, own estimates 
Figure 1.7. Real exchange rate in Poland in 1995,1 - 2009,2 (PLN/EUR)

E
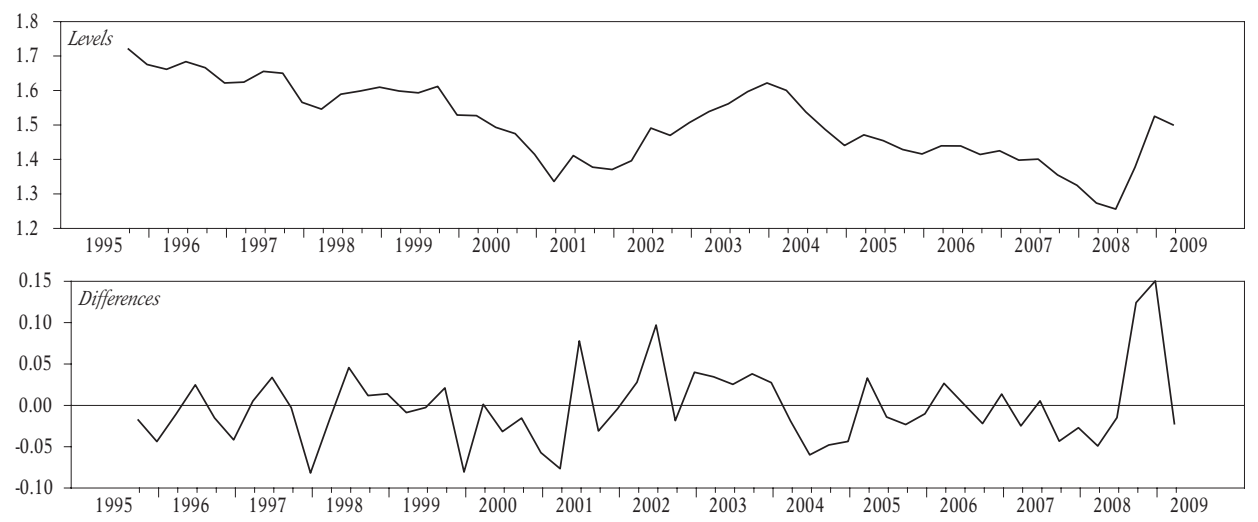

Source: CSO, www.stat.gov.pl, own estimates 
Annex 2

\section{Residual analysis}

DU
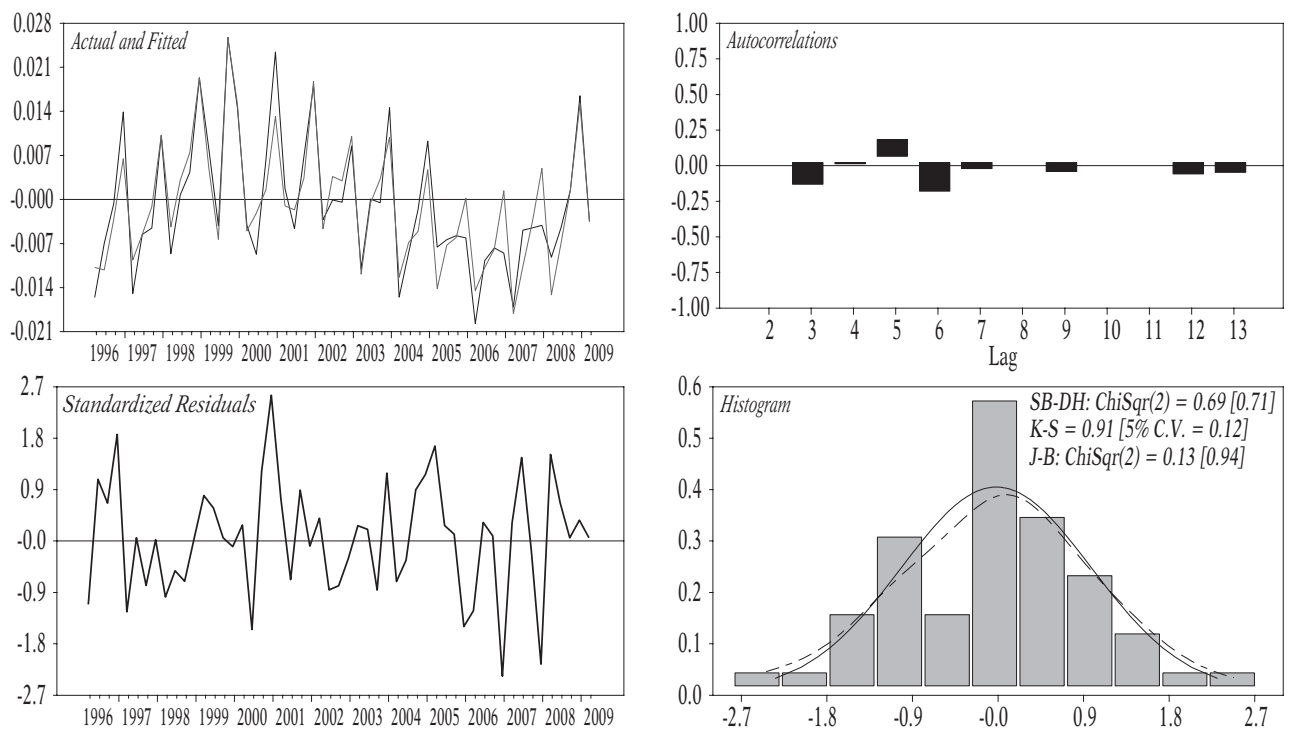

DY
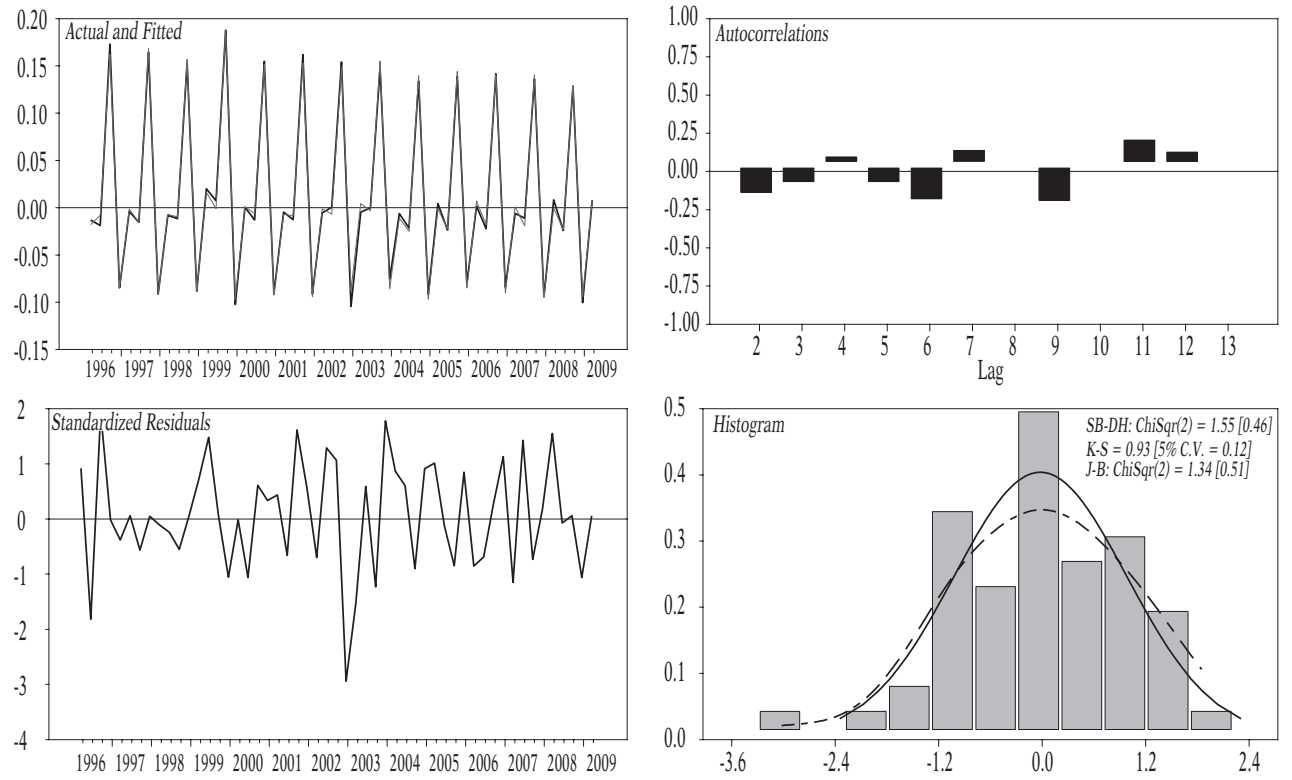
DW
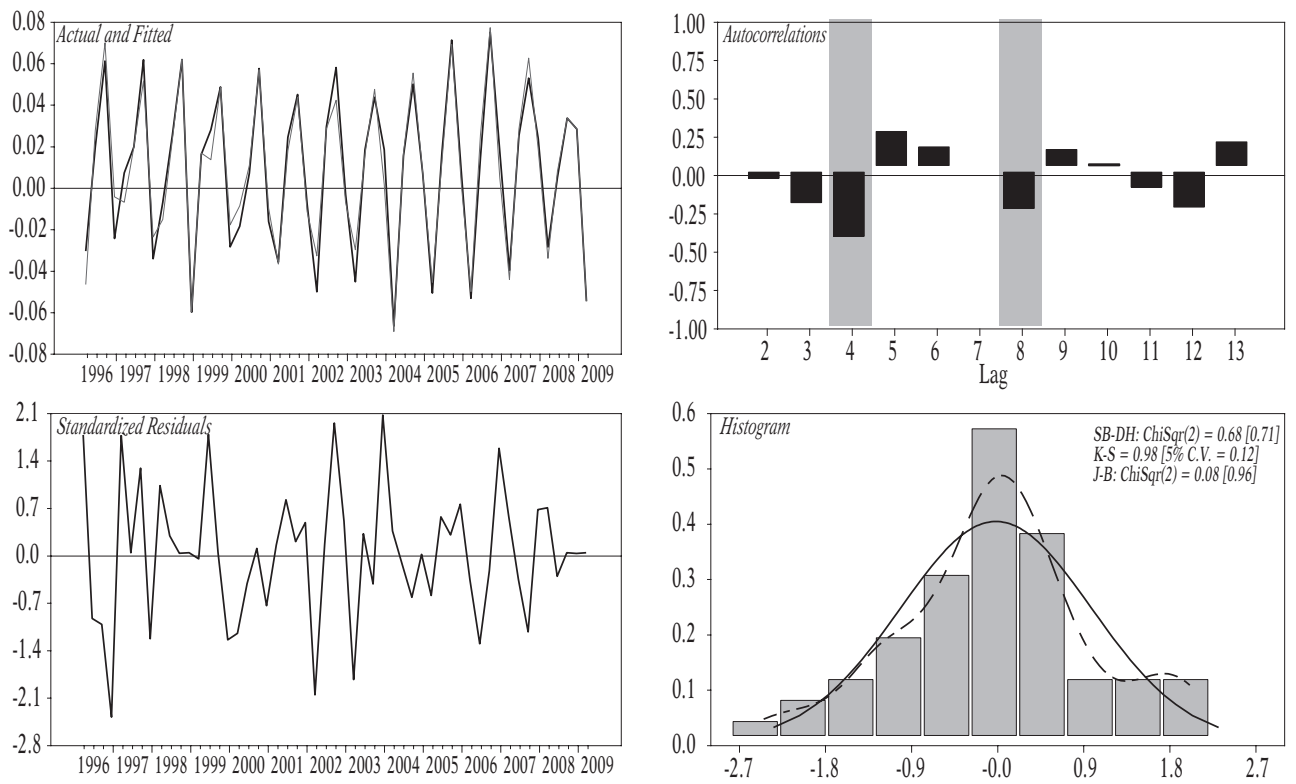

DDCPI
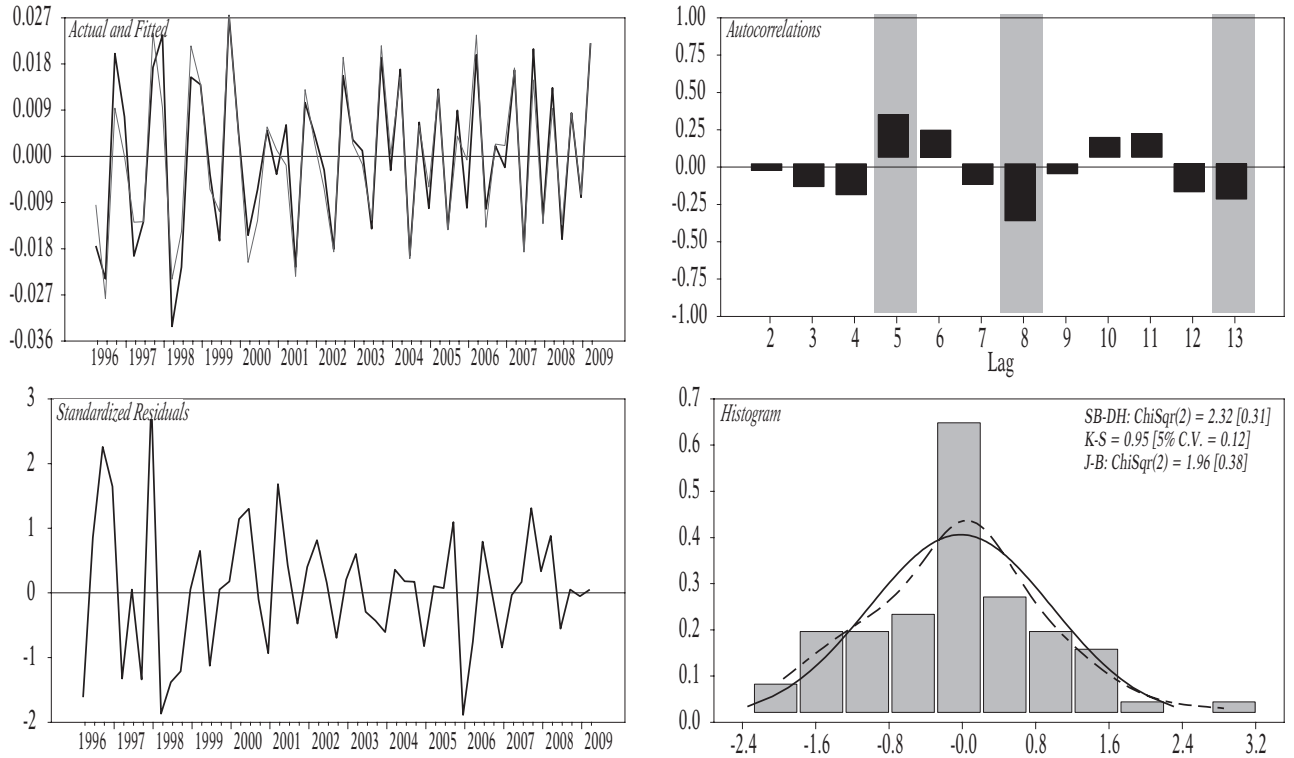
DPRICE_WEDGE
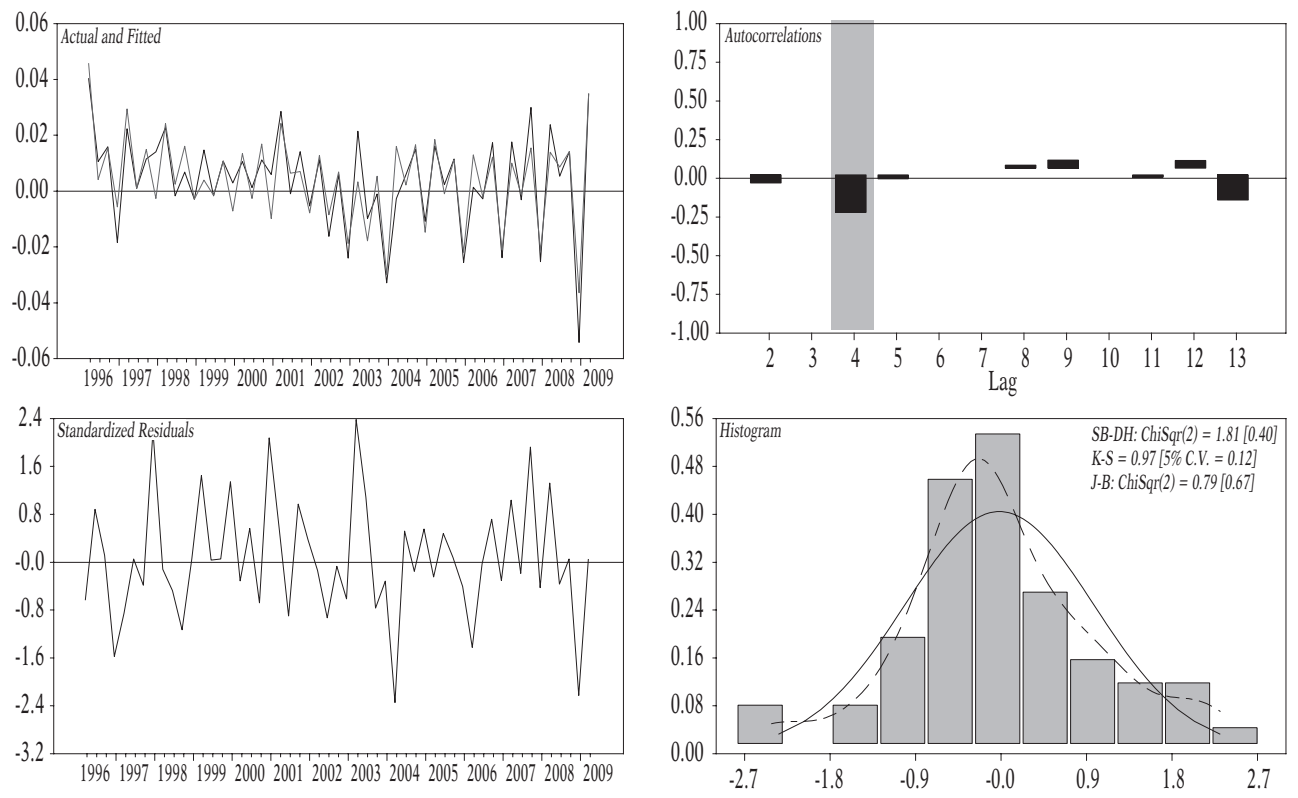

DR
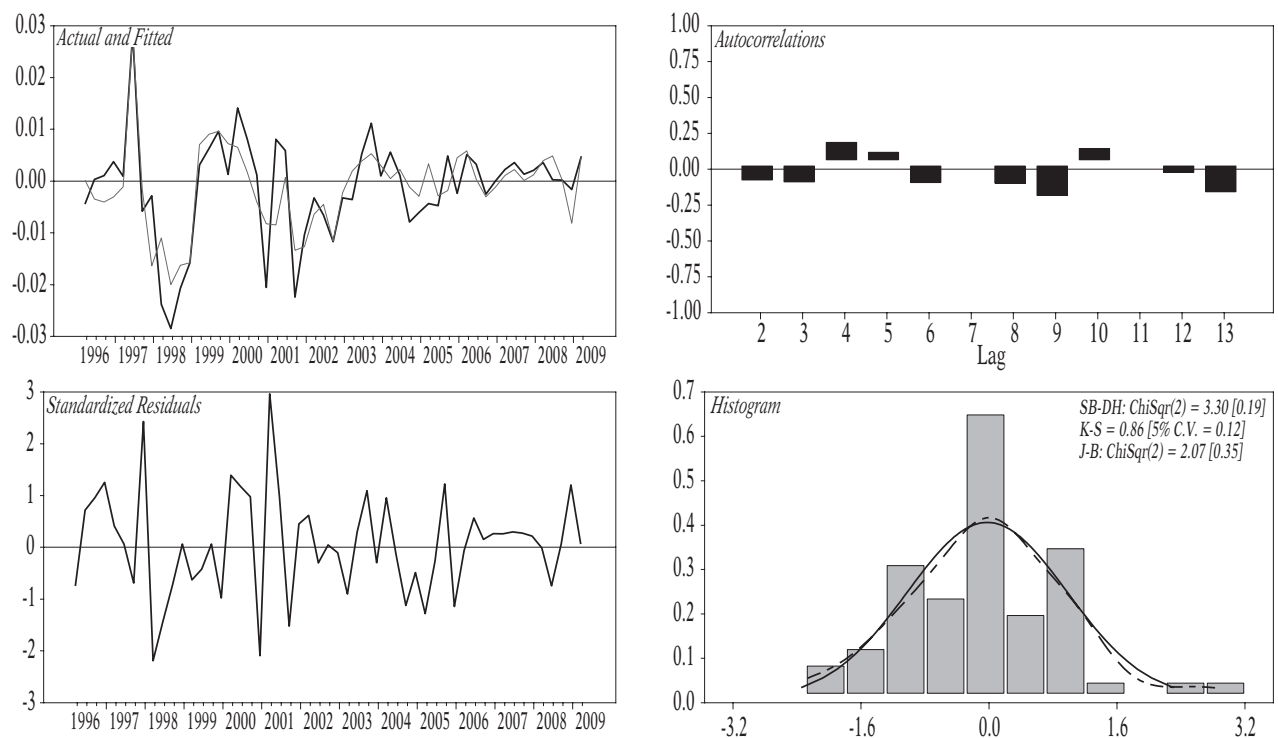
DE
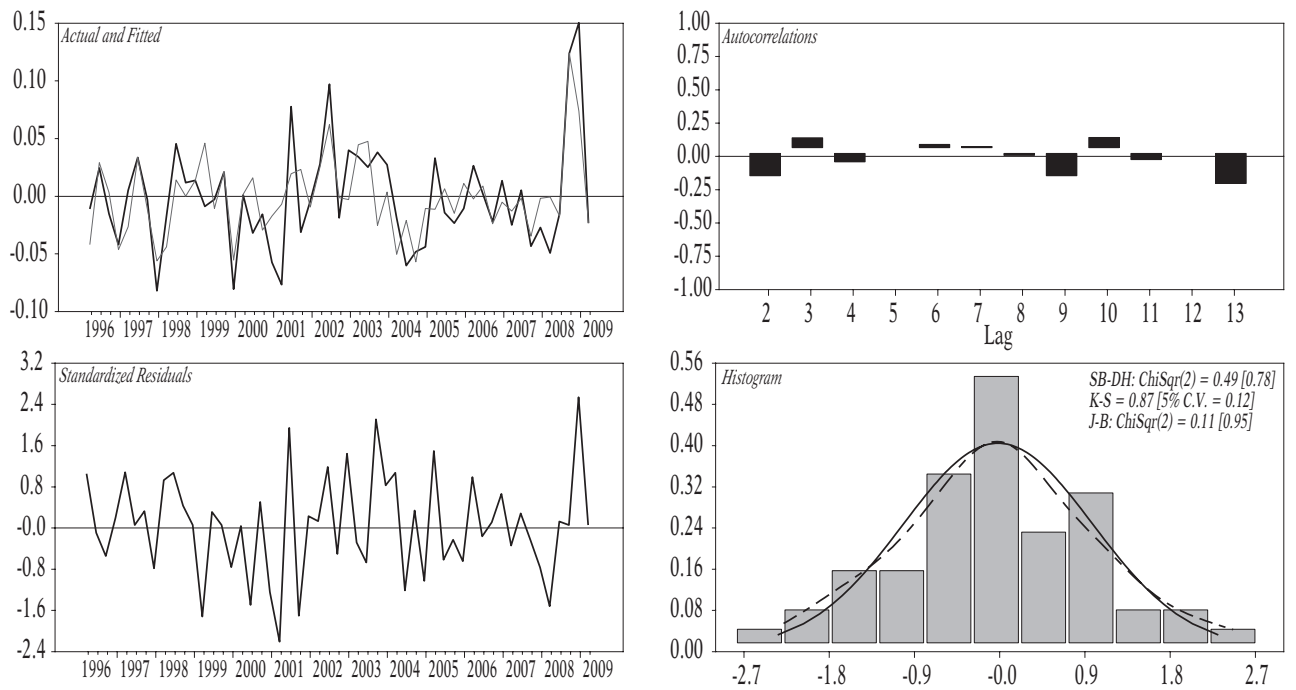


\section{Annex 3}

Table 3.1

Trace test results

\begin{tabular}{|c|c|c|r|r|r|c|c|}
\hline p-r & $\mathrm{r}$ & Eig. Value & Trace & \multicolumn{1}{c|}{ Trace* } & Frac95 & P-Value & P-Value* $^{*}$ \\
\hline 7 & 0 & 0.779 & 253.559 & 194.249 & 125.417 & 0.000 & 0.000 \\
\hline 6 & 1 & 0.674 & 173.486 & 133.361 & 95.514 & 0.000 & 0.000 \\
\hline 5 & 2 & 0.616 & 114.029 & 80.463 & 69.611 & 0.000 & 0.005 \\
\hline 4 & 3 & 0.418 & 63.291 & 46.735 & 47.707 & 0.001 & 0.062 \\
\hline 3 & 4 & 0.381 & 34.642 & 16.225 & 29.804 & 0.012 & 0.703 \\
\hline $\mathbf{2}$ & $\mathbf{5}$ & $\mathbf{0 . 1 3 1}$ & $\mathbf{9 . 2 2 4}$ & $\mathbf{5 . 5 1 1}$ & $\mathbf{1 5 . 4 0 8}$ & $\mathbf{0 . 3 5 2}$ & $\mathbf{0 . 7 5 3}$ \\
\hline 1 & 6 & 0.034 & 1.809 & 0.157 & 3.841 & 0.179 & 0.692 \\
\hline
\end{tabular}

Figure 3.1. The cointegrating vectors Beta1 $^{\prime *} \mathrm{Z} 1(\mathrm{t})$
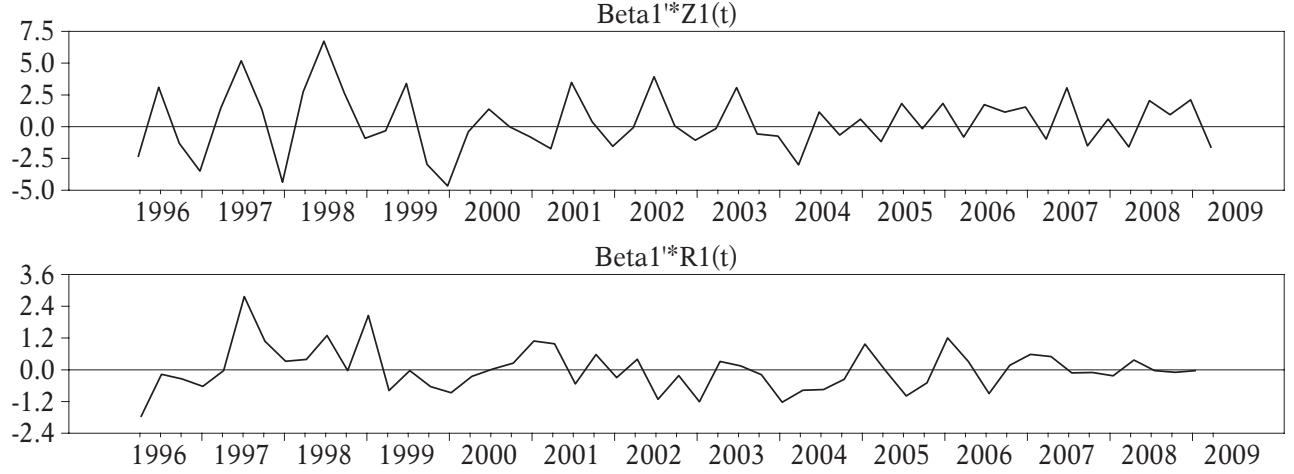

$\operatorname{Beta2}^{\prime *} \mathrm{Z} 1(\mathrm{t})$

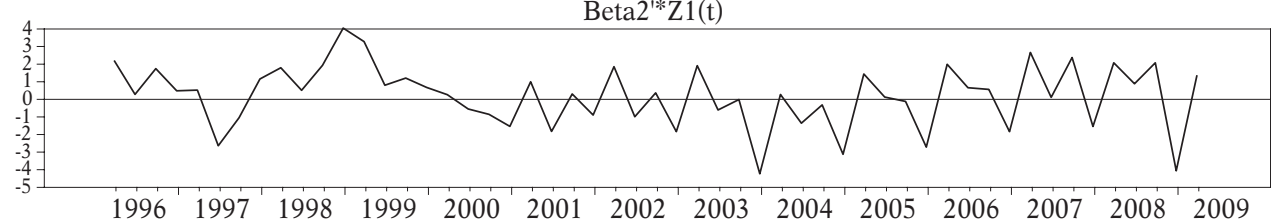

$\begin{array}{lllllllllllllll}1996 & 1997 & 1998 & 1999 & 2000 & 2001 & 2002 & 2003 & 2004 & 2005 & 2006 & 2007 & 2008 & 2009\end{array}$ Beta2 $^{\prime *} \mathrm{R} 1(\mathrm{t})$

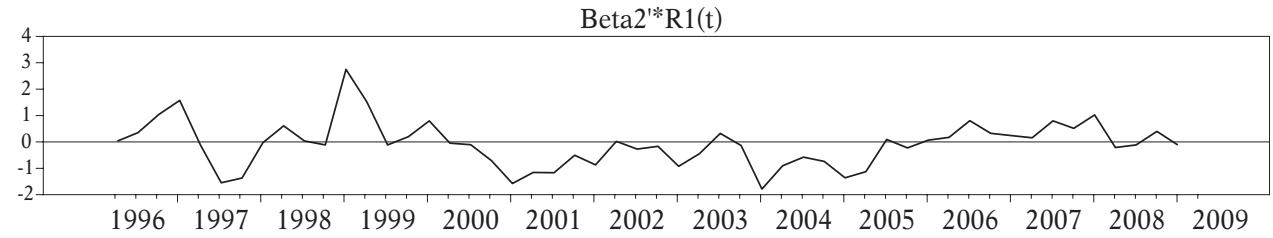




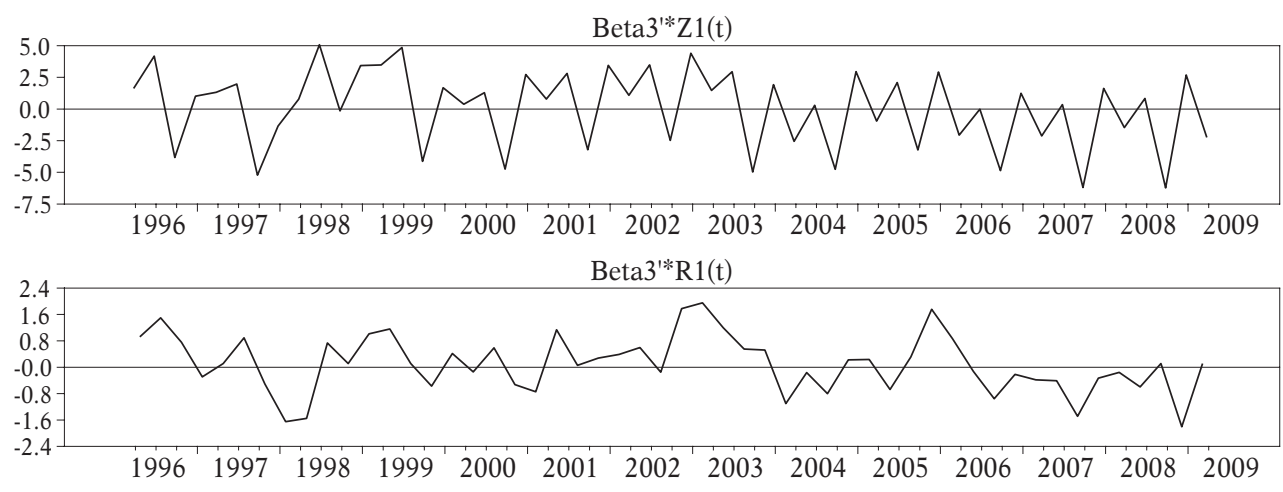

$\operatorname{Beta}^{\prime *} \mathrm{Z} 1(\mathrm{t})$

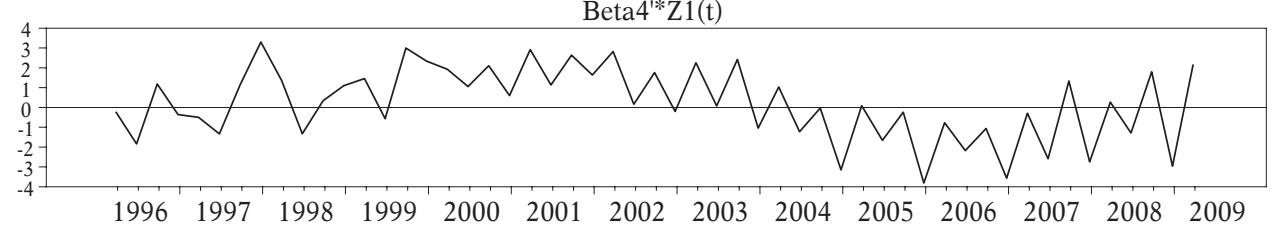

Beta4'R1(t)

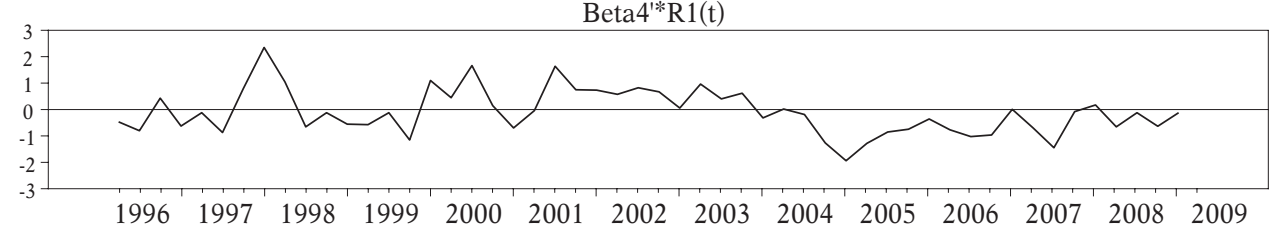

Beta5'Z1(t)

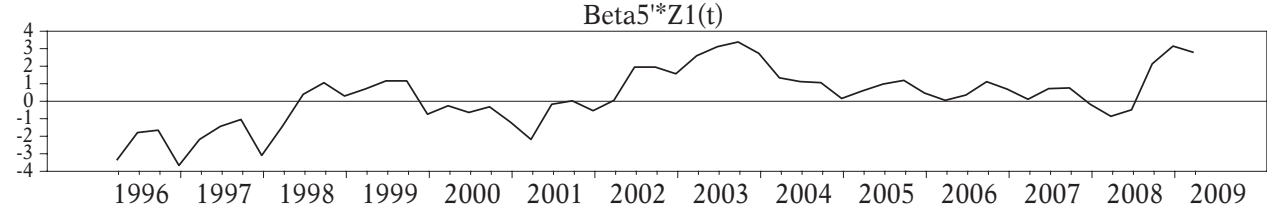

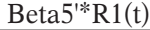

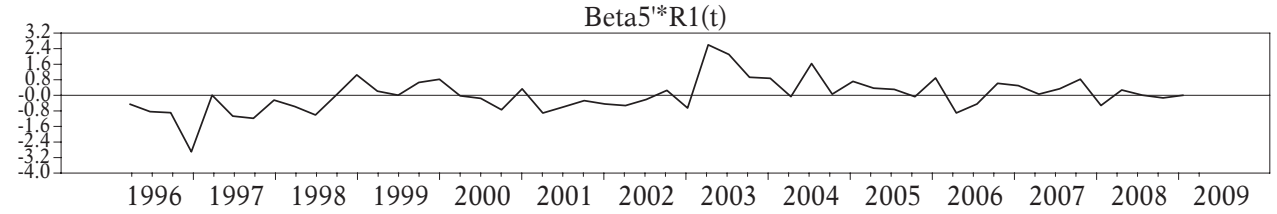



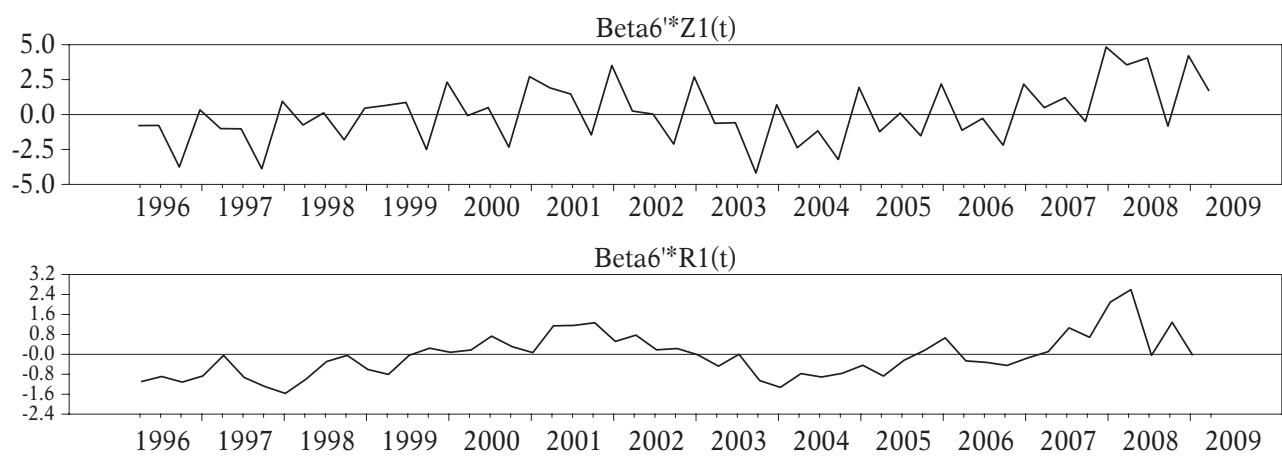

$\operatorname{Beta}^{1 *} \mathrm{Z} 1(\mathrm{t})$

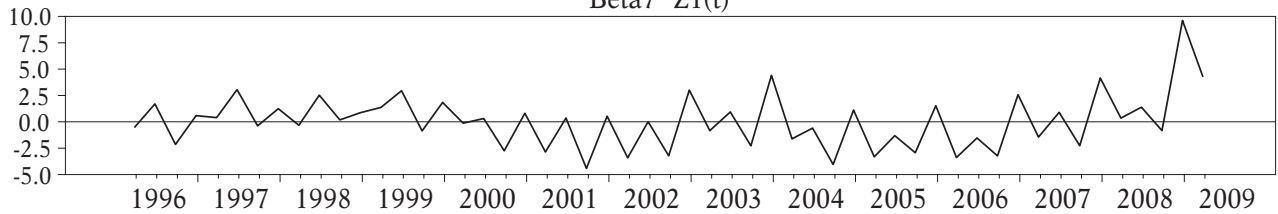

Beta7*R1(t)

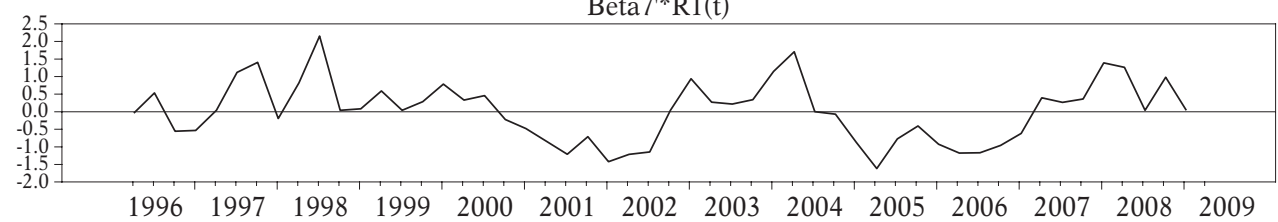

Table 3.2

Test of weak exogeneity (LR-Test, Chi-Square(r), P-values in brackets)

\begin{tabular}{|c|c|c|c|c|c|c|c|c|c|}
\hline $\mathrm{r}$ & DGF & $5 \%$ C.V. & $\mathrm{Y}$ & W & $\mathrm{U}$ & DCPI & E & $\mathrm{R}$ & PRICE_WEDGE \\
\hline 1 & 1 & 3.841 & $\begin{array}{c}4.788 \\
{[0.029]}\end{array}$ & $\begin{array}{c}0.198 \\
{[0.656]}\end{array}$ & $\begin{array}{c}5.494 \\
{[0.019]}\end{array}$ & $\begin{array}{c}9.152 \\
{[0.002]}\end{array}$ & $\begin{array}{c}0.710 \\
{[0.400]}\end{array}$ & $\begin{array}{c}0.420 \\
{[0.517]}\end{array}$ & $\begin{array}{c}0.477 \\
{[0.490]}\end{array}$ \\
\hline 2 & 2 & 5.991 & $\begin{array}{c}6.307 \\
{[0.043]}\end{array}$ & $\begin{array}{c}8.915 \\
{[0.012]}\end{array}$ & $\begin{array}{c}5.728 \\
{[0.057]} \\
\end{array}$ & $\begin{array}{c}14.880 \\
{[0.001]} \\
\end{array}$ & $\begin{array}{c}1.225 \\
{[0.542]}\end{array}$ & $\begin{array}{c}1.994 \\
{[0.369]}\end{array}$ & $\begin{array}{c}2.360 \\
{[0.307]}\end{array}$ \\
\hline 3 & 3 & 7.815 & $\begin{array}{l}23.566 \\
{[0.000]}\end{array}$ & $\begin{array}{l}28.931 \\
{[0.000]}\end{array}$ & $\begin{array}{c}5.841 \\
{[0.120]}\end{array}$ & $\begin{array}{c}17.427 \\
{[0.001]}\end{array}$ & $\begin{array}{c}4.792 \\
{[0.188]}\end{array}$ & $\begin{array}{c}5.538 \\
{[0.136]}\end{array}$ & $\begin{array}{c}3.052 \\
{[0.384]}\end{array}$ \\
\hline 4 & 4 & 9.488 & $\begin{array}{l}26.713 \\
{[0.000]}\end{array}$ & $\begin{array}{l}29.899 \\
{[0.000]}\end{array}$ & $\begin{array}{c}9.072 \\
{[0.059]}\end{array}$ & $\begin{array}{l}18.926 \\
{[0.001]}\end{array}$ & $\begin{array}{c}5.165 \\
{[0.271]}\end{array}$ & $\begin{array}{c}6.702 \\
{[0.153]}\end{array}$ & $\begin{array}{c}3.399 \\
{[0.493]}\end{array}$ \\
\hline 5 & 5 & 11.070 & $\begin{array}{l}34.268 \\
{[0.000]}\end{array}$ & $\begin{array}{l}40.485 \\
{[0.000]}\end{array}$ & $\begin{array}{c}18.903 \\
{[0.002]}\end{array}$ & $\begin{array}{c}29.350 \\
{[0.000]}\end{array}$ & $\begin{array}{c}5.169 \\
{[0.396]}\end{array}$ & $\begin{array}{l}22.250 \\
{[0.000]}\end{array}$ & $\begin{array}{l}14.196 \\
{[0.014]}\end{array}$ \\
\hline 6 & 6 & 12.592 & $\begin{array}{l}39.559 \\
{[0.000]}\end{array}$ & $\begin{array}{l}43.495 \\
{[0.000]}\end{array}$ & $\begin{array}{l}20.387 \\
{[0.002]}\end{array}$ & $\begin{array}{l}30.749 \\
{[0.000]}\end{array}$ & $\begin{array}{c}7.165 \\
{[0.306]}\end{array}$ & $\begin{array}{l}26.449 \\
{[0.000]}\end{array}$ & $\begin{array}{l}14.260 \\
{[0.027]}\end{array}$ \\
\hline
\end{tabular}


Table 3.3

Test of unit vector in alpha (LR-test, Chi-Square(7-r), P-values in brackets)

\begin{tabular}{|c|c|c|c|c|c|c|c|c|c|}
\hline $\mathrm{r}$ & DGF & 5\% C.V. & Y & $\mathrm{W}$ & $\mathrm{U}$ & DCPI & E & $\mathrm{R}$ & PRICE_WEDGE \\
\hline 1 & 6 & 12.592 & $\begin{array}{c}36.364 \\
{[0.000]}\end{array}$ & $\begin{array}{l}20.361 \\
{[0.002]}\end{array}$ & $\begin{array}{c}52.598 \\
{[0.000]}\end{array}$ & $\begin{array}{c}9.300 \\
{[0.157]}\end{array}$ & $\begin{array}{l}56.556 \\
{[0.000]}\end{array}$ & $\begin{array}{l}23.688 \\
{[0.001]}\end{array}$ & $\begin{array}{l}51.002 \\
{[0.000]}\end{array}$ \\
\hline 2 & 5 & 11.070 & $\begin{array}{c}15.876 \\
{[0.007]}\end{array}$ & $\begin{array}{c}6.338 \\
{[0.275]}\end{array}$ & $\begin{array}{c}32.285 \\
{[0.000]}\end{array}$ & $\begin{array}{c}8.592 \\
{[0.126]}\end{array}$ & $\begin{array}{l}36.684 \\
{[0.000]}\end{array}$ & $\begin{array}{l}16.876 \\
{[0.005]}\end{array}$ & $\begin{array}{l}33.570 \\
{[0.000]}\end{array}$ \\
\hline 3 & 4 & 9.488 & $\begin{array}{c}7.300 \\
{[0.121]}\end{array}$ & $\begin{array}{c}3.548 \\
{[0.471]}\end{array}$ & $\begin{array}{l}28.119 \\
{[0.000]}\end{array}$ & $\begin{array}{c}6.179 \\
{[0.186]}\end{array}$ & $\begin{array}{l}27.976 \\
{[0.000]}\end{array}$ & $\begin{array}{c}12.537 \\
{[0.014]}\end{array}$ & $\begin{array}{l}24.878 \\
{[0.000]}\end{array}$ \\
\hline 4 & 3 & 7.815 & $\begin{array}{c}6.193 \\
{[0.103]}\end{array}$ & $\begin{array}{c}0.453 \\
{[0.929]}\end{array}$ & $\begin{array}{c}10.340 \\
{[0.016]}\end{array}$ & $\begin{array}{c}0.165 \\
{[0.983]}\end{array}$ & $\begin{array}{l}15.214 \\
{[0.002]}\end{array}$ & $\begin{array}{l}11.075 \\
{[0.011]}\end{array}$ & $\begin{array}{c}7.502 \\
{[0.058]}\end{array}$ \\
\hline 5 & 2 & 5.991 & $\begin{array}{c}5.802 \\
{[0.055]}\end{array}$ & $\begin{array}{c}0.088 \\
{[0.957]}\end{array}$ & $\begin{array}{c}10.273 \\
{[0.006]}\end{array}$ & $\begin{array}{c}0.109 \\
{[0.947]}\end{array}$ & $\begin{array}{c}12.053 \\
{[0.002]}\end{array}$ & $\begin{array}{c}8.565 \\
{[0.014]}\end{array}$ & $\begin{array}{c}4.687 \\
{[0.096]}\end{array}$ \\
\hline 6 & 1 & 3.841 & $\begin{array}{c}0.059 \\
{[0.808]}\end{array}$ & $\begin{array}{c}0.088 \\
{[0.767]}\end{array}$ & $\begin{array}{c}2.086 \\
{[0.149]}\end{array}$ & $\begin{array}{c}0.108 \\
{[0.742]}\end{array}$ & $\begin{array}{c}0.716 \\
{[0.398]}\end{array}$ & $\begin{array}{c}2.419 \\
{[0.120]}\end{array}$ & $\begin{array}{c}1.546 \\
{[0.214]}\end{array}$ \\
\hline
\end{tabular}

Table 3.4

Test of joint unit vector in alpha

\begin{tabular}{|c|}
\hline CHISQR(6) $=\mathbf{5 . 1 4 1}[\mathbf{0 . 5 2 6}]$ \\
for unit vector in inflation rate, wages and price wedge \\
CHISQR(4) $=0.126[0.998]$ \\
for unit vector in inflation rate and wages \\
\hline CHISQR $(8)=17.881[0.022]$ \\
for unit vector in inflation rate, wages, productivity and price wedge \\
\hline CHISQR $(6)=7.909[0.245]$ \\
for unit vector in inflation rate, wages and productivity \\
\hline
\end{tabular}

Table 3.5

Identified beta structure

\begin{tabular}{|c|c|c|c|c|c|c|c|}
\hline \multicolumn{8}{|c|}{ BETA (transposed) } \\
\hline & $\mathrm{Y}$ & $\mathrm{W}$ & $\mathrm{U}$ & DCPI & $\mathrm{E}$ & $\mathrm{R}$ & PRICE_WEDGE \\
\hline $\operatorname{Beta}(1)$ & $\begin{array}{l}0.000 \\
\text { (.NA) }\end{array}$ & $\begin{array}{l}0.000 \\
\text { (.NA) }\end{array}$ & $\begin{array}{l}0.000 \\
\text { (.NA) }\end{array}$ & $\begin{array}{l}1.000 \\
\text { (.NA) }\end{array}$ & $\begin{array}{c}-0.069 \\
(-7.352)\end{array}$ & $\begin{array}{l}0.000 \\
\text { (.NA) }\end{array}$ & $\begin{array}{l}0.000 \\
\text { (.NA) }\end{array}$ \\
\hline $\operatorname{Beta}(2)$ & $\begin{array}{c}-0.796 \\
(-40.219)\end{array}$ & $\begin{array}{l}1.000 \\
\text { (.NA) }\end{array}$ & $\begin{array}{c}1.237 \\
(24.705)\end{array}$ & $\begin{array}{l}0.000 \\
\text { (.NA) }\end{array}$ & $\begin{array}{l}0.000 \\
\text { (.NA) }\end{array}$ & $\begin{array}{l}0.000 \\
\text { (.NA) }\end{array}$ & $\begin{array}{l}0.000 \\
\text { (.NA) }\end{array}$ \\
\hline $\operatorname{Beta}(3)$ & $\begin{array}{c}0.717 \\
(12.445)\end{array}$ & $\begin{array}{l}0.000 \\
\text { (.NA) }\end{array}$ & $\begin{array}{l}1.000 \\
\text { (.NA) }\end{array}$ & $\begin{array}{l}0.000 \\
\text { (.NA) }\end{array}$ & $\begin{array}{l}0.000 \\
\text { (.NA) }\end{array}$ & $\begin{array}{l}0.000 \\
\text { (.NA) }\end{array}$ & $\begin{array}{c}-2.175 \\
(-11.554)\end{array}$ \\
\hline $\operatorname{Beta}(4)$ & $\begin{array}{l}0.000 \\
\text { (.NA) }\end{array}$ & $\begin{array}{l}0.000 \\
\text { (.NA) }\end{array}$ & $\begin{array}{l}0.000 \\
\text { (.NA) }\end{array}$ & $\begin{array}{l}0.000 \\
\text { (.NA) }\end{array}$ & $\begin{array}{c}0.284 \\
(9.151)\end{array}$ & $\begin{array}{l}0.000 \\
\text { (.NA) }\end{array}$ & $\begin{array}{l}1.000 \\
\text { (.NA) }\end{array}$ \\
\hline $\operatorname{Beta}(5)$ & $\begin{array}{l}1.000 \\
\text { (.NA) }\end{array}$ & $\begin{array}{l}0.000 \\
\text { (.NA) }\end{array}$ & $\begin{array}{l}0.000 \\
\text { (.NA) }\end{array}$ & $\begin{array}{c}-3.872 \\
(-18.397)\end{array}$ & $\begin{array}{c}0.266 \\
(4.309)\end{array}$ & $\begin{array}{c}3.872 \\
(18.397)\end{array}$ & $\begin{array}{l}0.000 \\
\text { (.NA) }\end{array}$ \\
\hline
\end{tabular}




\section{Wages, Prices and Unemployment in Poland}

\section{S u m mary}

The paper aims to analyze long-run relationships between labor market trends, wages, prices, interest rates and the exchange rate in Poland. We use a research approach known as cointegrated VAR analysis, which makes it possible to identify long-run tendencies and common stochastic trends as well as estimate the adjustment dynamics of the system (the pulling and pushing forces). The results show that we can find stable long-run cointegration relationships between the unemployment rate, wages and prices. We can confirm our two main research hypotheses formulated on the basis of theoretical formulations. First of all, increasing product market competition seems to be the main driving force behind the convergence of the Polish economy with more advanced European economies during the analyzed period. Second, we can confirm that the Polish inflation rate has adapted to the European purchasing power parity level over the long run, and we can also confirm a kind of Balassa-Samuelson effect on consumer prices.

Keywords: cointegrated VAR model, labor market in Poland, price adjustments 